\title{
FUNCTIONAL DEPENDENCE ON CONSTRUCTION COSTS OF HORIZONTAL MINING FACILITIES IN LEAD-ZINC ORE
}

\section{ZAVISNOST TROŠKOVA IZRADE HORIZONTALNIH RUDARSKIH PROSTORIJA U RUDI OLOVA I CINKA}

\author{
Doneva Nikolinka ${ }^{1}$, Hadži-Nikolova Marija ${ }^{1}$, Lutovac Suzana ${ }^{2}$
}

Received: May 12, 2014

Accepted: June 4, 2014

\begin{abstract}
This paper presents a methodology for determination of the twoparameter dependence on construction costs of horizontal mining facilities in the lead-zinc ore. Construction costs are shown as a function of the profile area on facilities and the degree of jointed on the rock, presented by the change in their uniaxial compressive strength.
\end{abstract}

Key words: profile, ore deposit, scientific research

Apstrakt: U ovom radu dat je način određivanja dvoparametarske zavisnosti troškova izrade horizontalnih rudarskih prostorija u rudi olova i cinka. Troškovi izrade su prikazani kao funkcija površine profila prostorije i stepena ispucalosti radne sredine-predstavljene preko promene jednoaksijalne pritisne cvrstoće stenske mase.

Ključne reči: profil, ležište, istraživanje

\section{INTRODUCTION}

Horizontal mining facilities, such as pits, crosscutting drifts, longitudinal drifts etc., can be constructed in surrounding rocks, underburden or usually overburden, also in the ore deposit. The route of horizontal mining facilities primarily depends on: physical and mechanical properties of surrounding rocks and ore deposits, as on the thickness and way of providing the ore body, the construction costs and the projected mining method.

It should be noted that within same types of rock exist zones with different structural characteristics, regardless where mining facilities will be constructed either in surrounding rocks or ore body. Different properties create a difference in stability of the rock material. Therefore, is essential for any rock type to determine its structural

\footnotetext{
${ }^{1}$ University "Goce Delčev", Faculty of Natural and Technical Sciences, Mining Institute, Krste Misirkov 10A, 2000 Štip, Republic of Macedonia, e-mail: nikolinka.doneva@ugd.edu.mk

${ }^{2}$ University of Belgrade - Faculty of Mining and Geology, Đušina 7, 11000 Belgrade, Serbia, e-mail: suzana.lutovac@rgf.bg.ac.rs
} 
properties such as: discontinuity plane orientation, the degree of jointed on rock material, joint and joint family, as and stability of each block, located adjacent to underground facilities (Brady and Brown 2006).

\section{CREATING A MATHEMATICAL MODEL ON HORIZONTAL MINING FACILITIES CONSTRUCTION IN LEAD- ZINC ORE}

As earlier stated, this paper analyze horizontal mining facilities construction in the lead-zinc ore. Table 1 shows physical and mechanical properties of lead-zinc ore from the deposit "Sasa" M.Kamenica obtained by laboratory tests including: bulk density $\gamma\left[\mathrm{MN} / \mathrm{m}^{3}\right]$, uniaxial compressive strength $\sigma_{\mathrm{c}}[\mathrm{MPa}]$, tensile strength $\sigma_{\mathrm{t}}[\mathrm{MPa}]$, cohesion $\mathrm{C}[\mathrm{MPa}]$, angle of internal friction $\varphi\left[^{\circ}\right]$, Poisson`s coefficient $v$ and modul of elasticity $\mathrm{E}[\mathrm{MPa}]$.

Table 1 - Physical and mechanical properties of anticipated rocks type

\begin{tabular}{|c|c|c|c|c|c|c|c|}
\hline Description & $\begin{array}{c}\gamma \\
{\left[\mathbf{M N} / \mathbf{m}^{3}\right]}\end{array}$ & $\begin{array}{c}\sigma_{\mathbf{c}} \\
{[\mathbf{M P a}]}\end{array}$ & $\begin{array}{c}\sigma_{\mathbf{t}} \\
{[\mathbf{M P a}]}\end{array}$ & $\begin{array}{c}\mathbf{C} \\
{[\mathbf{M P a}]}\end{array}$ & $\begin{array}{c}\varphi \\
{\left[{ }^{\circ}\right]}\end{array}$ & $\boldsymbol{v}$ & $\begin{array}{c}\mathbf{E} \\
{[\mathbf{M P a}]}\end{array}$ \\
\hline \hline Lead-zinc ore & 0.0377 & 142 & 17.00 & 28.5 & 46.5 & 0.245 & 69500 \\
\hline
\end{tabular}

In this mathematical model have been created nine variants, so that have been adopted three sizes of mining facilities profile (Figure 1) and three degrees of jointed rock type. This is given in Table 3 .

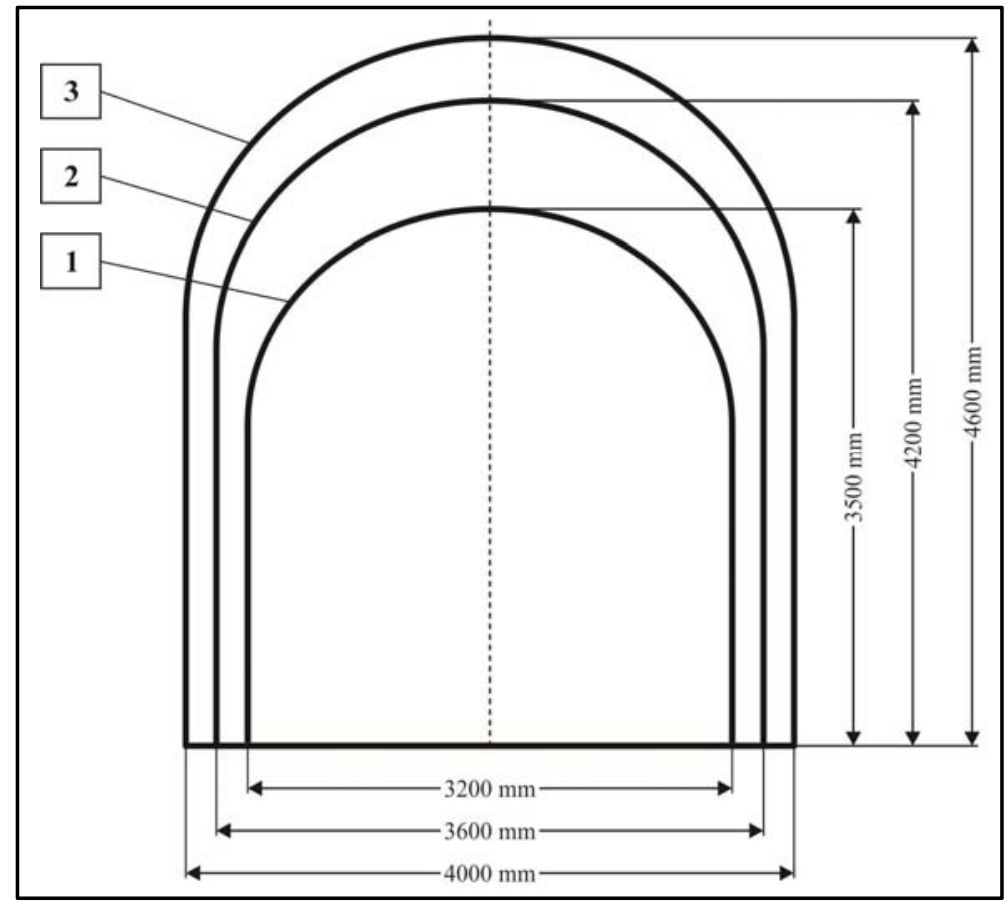

Figure 1 - Adopted size of underground mining facilities profile 
Uniaxial compressive strength of three degrees jointed was calculated by following formula:

$$
\frac{\sigma_{c s m}}{\sigma_{c}}=e^{-0.008 \cdot J_{f}}, \quad[\mathrm{MPa}]
$$

where are:

$\sigma_{c s m}$ - uniaxial compressive strength of rock material, [MPa];

$\sigma_{c}$ - uniaxial compressive strength of intact rock, [MPa];

$J_{f}$ - joints factor.

$$
J_{f}=\frac{J_{n}}{n \cdot r}
$$

where are:

$J_{n}$ - joints number per $1 \mathrm{~m},[$ no. $/ \mathrm{m}]$;

$n$ - inclination parameter, depending on the inclination of joints plane by major effective principal stresses (Table 2);

$r$ - factor of joints, $r=\tan \varphi$.

Table 2 - Parameter on joint inclination

\begin{tabular}{|l||c|c|c|c|c|c|c|c|c|c|}
\hline $\begin{array}{l}\text { Angle on joint } \\
\text { orientations, } \boldsymbol{\beta}\end{array}$ & 0 & 10 & 20 & 30 & 40 & 50 & 60 & 70 & 80 & 90 \\
\hline $\begin{array}{l}\text { Parameter on joint } \\
\text { Inclination, } \mathbf{n}\end{array}$ & 0.82 & 0.46 & 0.11 & 0.05 & 0.09 & 0.30 & 0.46 & 0.64 & 0.82 & 0.95 \\
\hline
\end{tabular}

\begin{tabular}{|c|c|c|c|c|c|c|c|}
\hline $\begin{array}{l}\text { Rock } \\
\text { type }\end{array}$ & $\begin{array}{c}\text { Uniaxial } \\
\text { compres } \\
\text { strength of } \\
\text { intact rock } \\
\sigma_{\mathrm{c}} \\
{[\mathrm{MPa}]}\end{array}$ & $\begin{array}{c}\text { Spacing } \\
\text { of joints } \\
\text { l } \\
{[\mathrm{m}]}\end{array}$ & $\begin{array}{c}\begin{array}{c}\text { Number } \\
\text { of joints } \\
\text { per } 1 \mathrm{~m}\end{array} \\
\mathbf{J}_{\mathbf{n}} \\
{[\mathrm{no.} / \mathrm{m}]}\end{array}$ & $\begin{array}{c}\begin{array}{c}\text { Factor } \\
\text { of joints }\end{array} \\
\mathbf{J}_{\mathbf{f}}\end{array}$ & $\begin{array}{c}\text { Uniaxial } \\
\text { compresive } \\
\text { strength of } \\
\text { rock mass } \\
\sigma_{\mathrm{cm}} \\
{[\mathrm{MPa}]}\end{array}$ & $\begin{array}{c}\text { Anticipated } \\
\text { cross-section } \\
\left.\qquad \mathbf{m}^{2}\right]\end{array}$ & $\begin{array}{l}\text { Tag in } \\
\text { model }\end{array}$ \\
\hline \multirow{9}{*}{$\begin{array}{l}\text { Lead-zinc } \\
\text { ore }\end{array}$} & \multirow{9}{*}{142} & \multirow{3}{*}{0.65} & \multirow{3}{*}{1.54} & \multirow{3}{*}{29.22} & \multirow{3}{*}{112} & 10.10 & A1 \\
\hline & & & & & & 13.73 & $\mathrm{~A} 2$ \\
\hline & & & & & & 16.68 & A3 \\
\hline & & \multirow{3}{*}{0.50} & \multirow{3}{*}{2.00} & \multirow{3}{*}{37.99} & \multirow{3}{*}{105} & 10.10 & B1 \\
\hline & & & & & & 13.73 & B2 \\
\hline & & & & & & 16.68 & B3 \\
\hline & & \multirow{3}{*}{0.40} & \multirow{3}{*}{2.50} & \multirow{3}{*}{47.49} & \multirow{3}{*}{97} & 10.10 & $\mathrm{C} 1$ \\
\hline & & & & & & 13.73 & $\mathrm{C} 2$ \\
\hline & & & & & & 16.68 & C3 \\
\hline
\end{tabular}

Table 3 - Variants of horizontal mining facilities in model

So the degree of jointed rock material and size of mining facilities profile presents variants in the mathematical model. To obtain data that can be compared, other influential parameters in the mining construction system is needed to be same in all mining facilities (Донева, 2011).

Construction system includes these fixed parameters:

- $\quad$ Cross-sectional shape of mining facilities - horse - shoe shaped;

- $\quad$ The average depth of same route - $500 \mathrm{~m}$; 
- Work management - related technological cycle will be apply, with precisely defined of work operations duration;

- $\quad$ Drilling and blasting will be applied as construction method of mining facilities (Doneva et al. 2013).

\section{PARAMETERS OF WORK OPERATIONS}

Blast holes diameter is $\varnothing 45 \mathrm{~mm}$ for all variants, except central blank (ø6 $64 \mathrm{~mm}$ ). The prismatic cut was also applied, while blasting was performed using AMONEKS 3 explosive, product by "Trayal" corporation, Kruševac, R.Serbia. In auxiliary and cuts blast holes cartridges with $ø 38 \mathrm{~mm}$ will be used, while in flaking, $ø 28 \mathrm{~mm}$. Calculated parameters of drilling and blasting are given in Table 4.

After each blasting, a break of 30 minutes is needed when work area is absolve from dangerous gases of blasting using local ventilation systems. Ventilation parameters are given in Table 5 .

Input parameter of loading and transportation is quantity on the bulk material produced during one blasting. Average distance LHD machine is $100 \mathrm{~m}$, while on the mine truck is $800 \mathrm{~m}$. These parameters are given in Table 6 .

Shotcrete with a thickness $(3 \mathrm{~cm})$ that is determined calculating underground pressure and resistance of shotcrete and rock arch is used as supporting materials (Донева et al. 2008). Supporting parameters are given in Table 7.

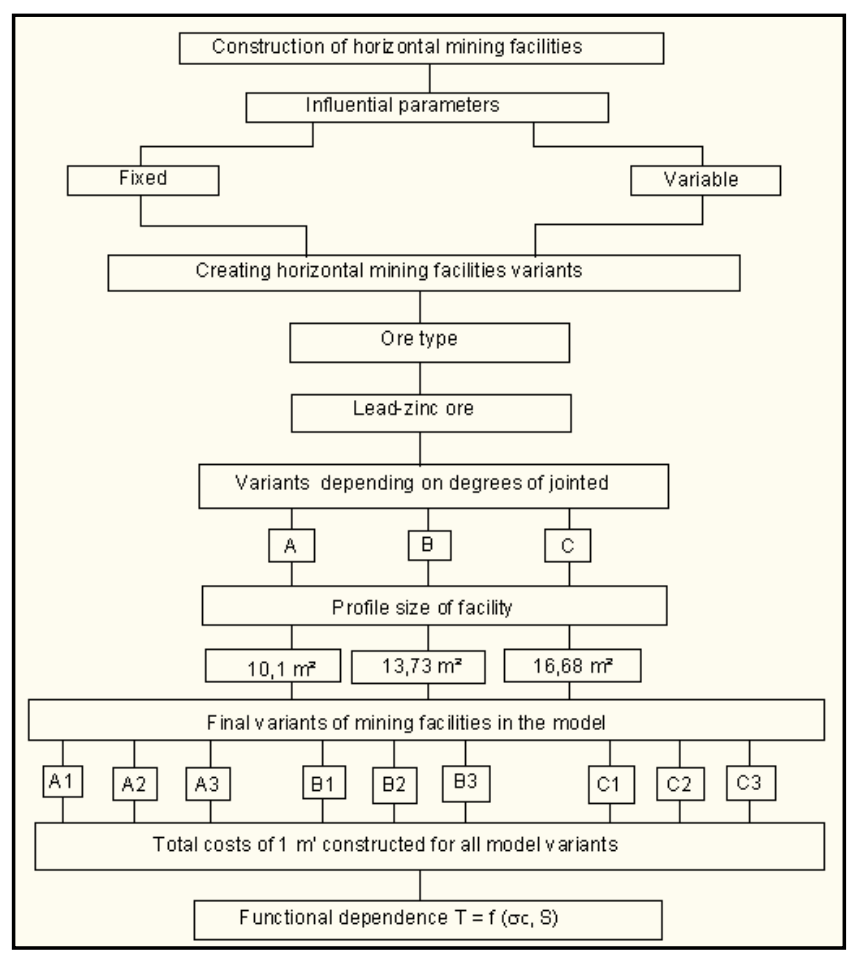

Figure 2 - Mathematical model 

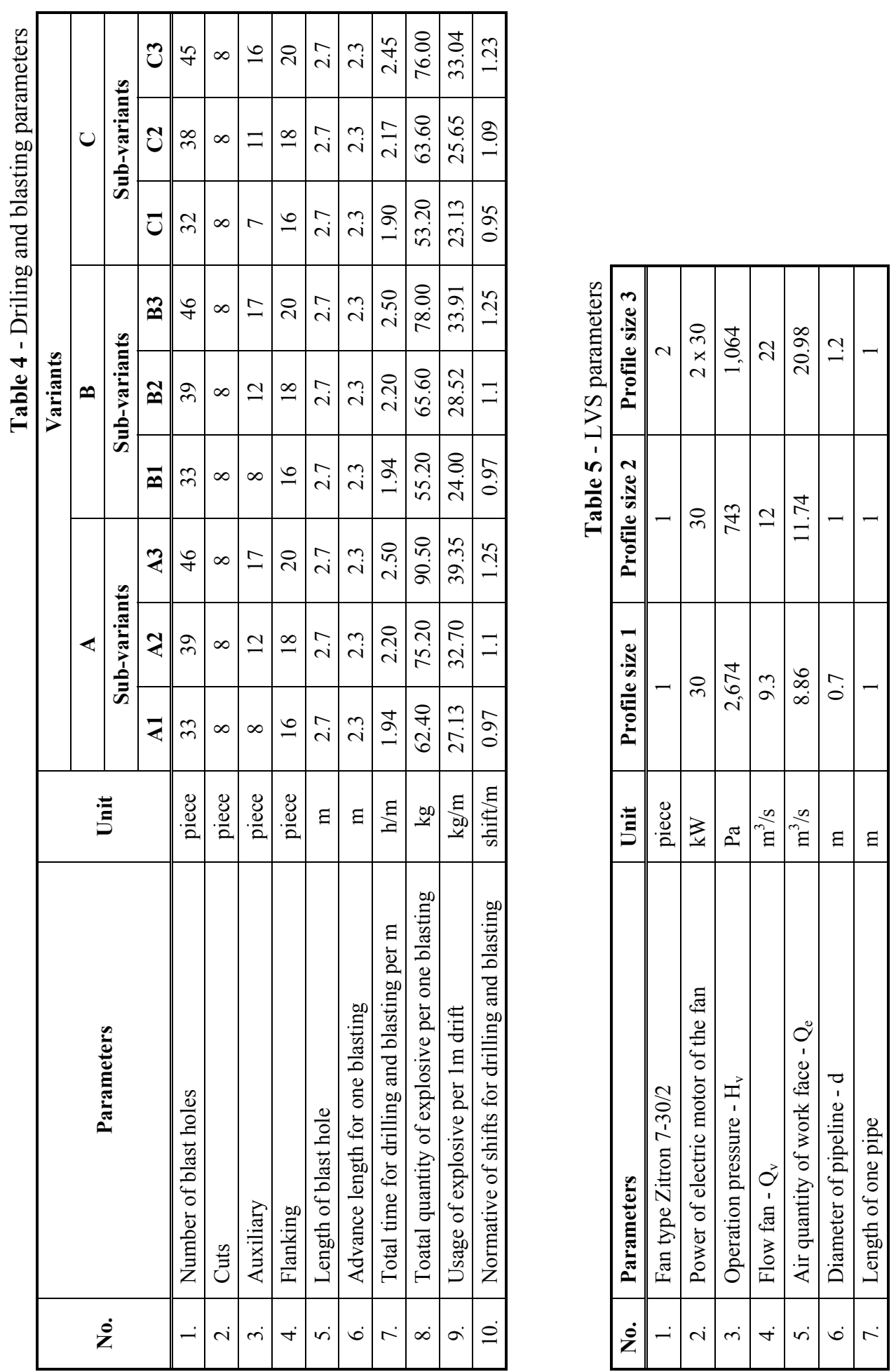
Doneva N.; Hadži-Nikolova M.; Lutovac S.
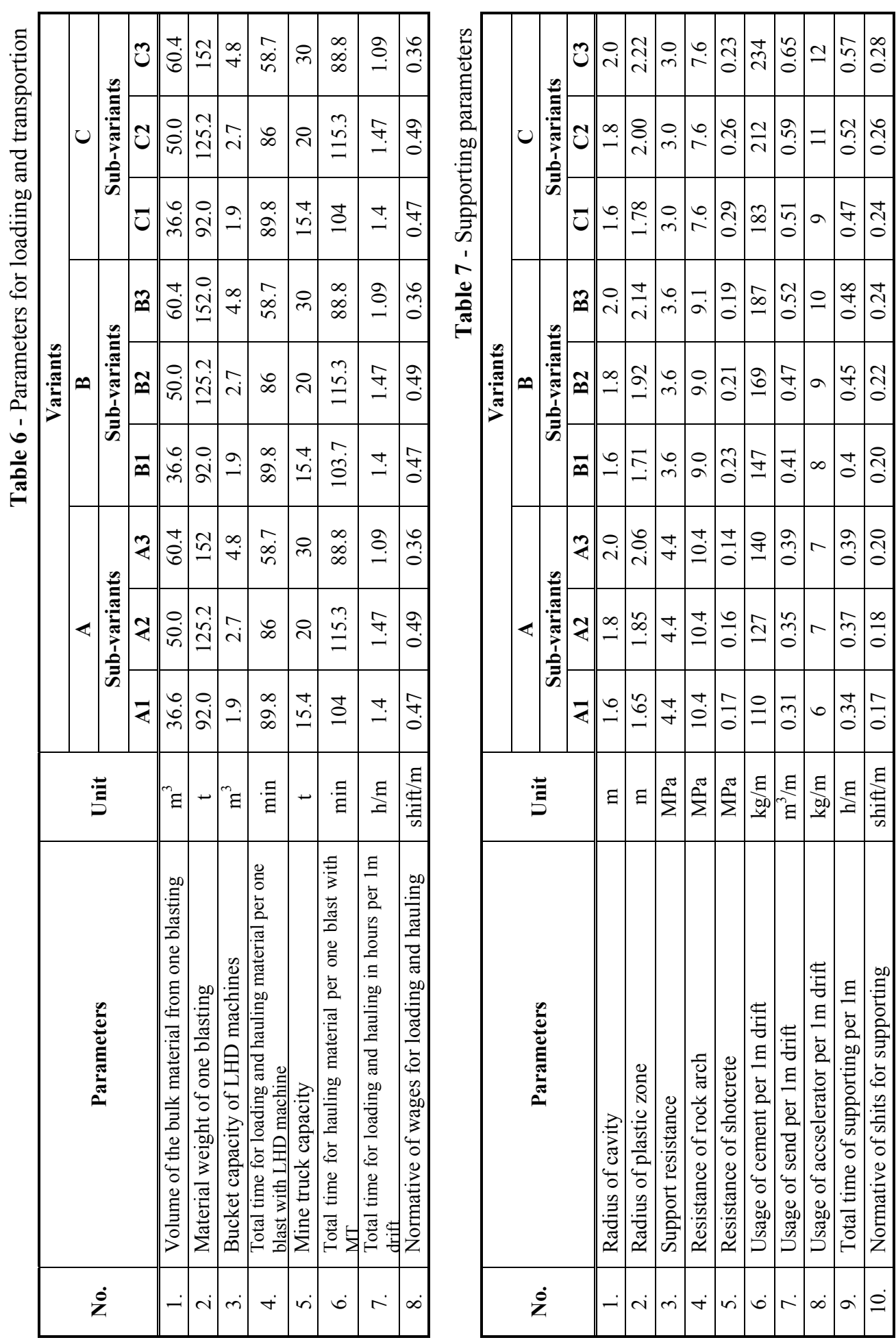


\section{CONSTRUCTION COSTS OF NINE FACILITIES VARIANTS}

Based on calculation parameters and price of materials, the cost of mechanization and gross shifts, construction costs by working operations as well as total costs were obtained (Table 8).

Table 8 - Total construction cost

\begin{tabular}{|l||c|c|c|c|c|c|c|c|c|}
\hline \multicolumn{1}{|c|}{$\begin{array}{c}\text { Const. costs } \\
{[\boldsymbol{\epsilon} / \mathbf{m}]}\end{array}$} & A1 & $\mathbf{A 2}$ & $\mathbf{A 3}$ & $\mathbf{B 1}$ & $\mathbf{B 2}$ & $\mathbf{B 3}$ & $\mathbf{C 1}$ & $\mathbf{C 2}$ & $\mathbf{C 3}$ \\
\hline $\begin{array}{l}\text { Costs for drilling } \\
\text { and blasting }\end{array}$ & 151.5 & 169.4 & 187.9 & 148.1 & 164.8 & 181.8 & 146.7 & 163.4 & 180.5 \\
\hline $\begin{array}{l}\text { Costs of } \\
\text { ventilation }\end{array}$ & 16.0 & 21.7 & 34.9 & 16.1 & 21.8 & 35.2 & 16.2 & 21.9 & 35.4 \\
\hline $\begin{array}{l}\text { Costs of loading and } \\
\text { transportation }\end{array}$ & 108.7 & 114.3 & 106.6 & 108.7 & 114.3 & 106.6 & 108.7 & 114.3 & 106.6 \\
\hline $\begin{array}{l}\text { Costs of } \\
\text { supporting }\end{array}$ & 65.4 & 74.2 & 81.9 & 75.6 & 86.0 & 94.9 & 85.8 & 97.7 & 107.9 \\
\hline $\begin{array}{l}\text { Costs of auxiliary } \\
\text { w. operations }\end{array}$ & 34.0 & 34.9 & 37.3 & 33.2 & 35.4 & 37.7 & 34.0 & 36.4 & 38.8 \\
\hline $\begin{array}{l}\text { Total construction } \\
\text { cost of 1m horizontal } \\
\text { mining facilities [€/m] }\end{array}$ & 375.6 & 414.4 & 448.6 & 381.6 & 422.3 & 456.3 & 391.3 & 433.7 & 469.3 \\
\hline
\end{tabular}

\section{FUNCTIONAL DEPENDENCY}

Based on calculated construction cost of horizontal mining facilities, using a computer program OM Explorer, upgrade on the Excel program, a two-parameter functional dependence of construction costs have been established: from the rock type and the profile size in the following form:

$$
z=c+a \cdot x+b \cdot y
$$

Where as:

$x$ - uniaxial compressive strength of rock mass [MPa];

$y$ - profile size of facility $\left[\mathrm{m}^{2}\right]$,

presents independent variables, while

$z$ - construction cost of horizontal mining facility [€/m],

$c$ - constant; is dependent variable

$a, b$ - constants before independent variables.

Following values of coefficients are obtained:

$$
\begin{aligned}
& c=388.702 \\
& a=-1.154 \\
& b=11.395
\end{aligned}
$$

$$
z=388.702-1.154 x+11.395 y
$$

This functional dependence is shown graphically on Figure 3. 


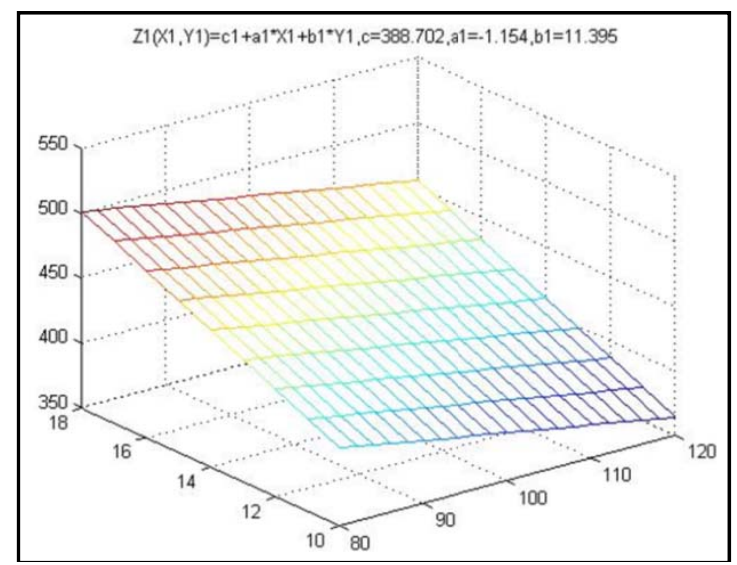

Figure 3 - Two-parameter functional dependence of construction costs

Table 8 and Figure 1 show that with increasing strength, costs will be decreased, while they will be increased in case of increasing profile size.

\section{CONCLUSION}

This scientific research indicates that different strength properties of rock material and size profiles lead to differences in construction costs on horizontal mining facilities.

Therefore is essential during projecting mining facilities to pay attention on selection of optimal route and determination of optimal profile size in terms of construction costs, as well as from the aspect of continuous production at the mine.

\section{ACKNOWLEDGEMENT}

This paper was realized as a part of the project "Research on possibility of AT (Advanced Technology) rockbolting application in mines for the purpose of work safety increase and production efficiency" (TR 33025) financed by the Ministry of Education, Science and Techonological Development of the Republic of Serbia within the framework of Programme of research in the field of technological development for the period 2011-2015. 


\section{REFERENCES}

[1] BRADY, B. and BROWN, E.T (2006) Rock mechanics for underground mining. Queensland: University of Western Australia.

[2] ДОНЕВА, Н. et al. (2008) Компаративна анализа за подградување на хоризонтална рударска просторија со еластична и дрвена подграда. II стручно советување на тема: Технологија на подземна експлоатација на минерални суровини - ПОДЕКС '08, М. Каменииа, декември 2008. Скопје: Здружение на рударски и геолошки инженери на Република Македонија, pp. 89-103.

[3] ДОНЕВА, Н. (2011) Методологија за утврдување на функиионалната зависност на трошоците од видот на работната средина и големината на профилот при изработка на хоризонтална рударска просторија. (PhD), Универзитет „Гоце Делчев“ Штип.

[4] DONEVA, N. et al. (2013) Construction of horizontal mining facilities through schist's massive. In: Proceedings of the 5th Jubilee Balkan Mining Congress, Ohrid, September 2013. Skopje: Association of Mining and Geological Engineers of Macedonia, pp. 721-725. 